\title{
ENZYMATIC BIOREMEDIATION OF ENDOSULFAN IN SOIL USING LIGNINOLYTIC EXTRACT OF SPENT MUSHROOM COMPOST OF PLEUROTUS OSTREATUS
}

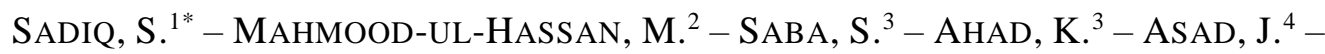 \\ MEHMOOD, R. T. ${ }^{5}-$ TAJ, T. $^{3}$ \\ ${ }^{I}$ PARC Institute of Advanced Studies in Agriculture, Quaid-i-Azam University \\ Islamabad, Pakistan \\ ${ }^{2}$ Land Resources Research Institute, National Agriculture Research Center \\ Islamabad, Pakistan
}

${ }^{3}$ Ecotoxicology Research Program, National Agriculture Research Center, Islamabad, Pakistan

${ }^{4}$ Department of Biochemistry, PMAS Arid Agriculture University

Murree Road, Rawalpindi, Pakistan

${ }^{5}$ Department of Biotechnology, Mirpur University of Science and Technology

Mirpur-10250 (AJK), Pakistan

*Corresponding author

e-mail: saimasadiqqau@yahoo.com

(Received 28 $8^{\text {th }}$ Jul 2018; accepted $31^{\text {st }}$ Oct 2018)

\begin{abstract}
Endosulfan is known for its non target toxicity in various compartments of ecosystem. Its presence in hotspots and agricultural fields is an environmental concern. In this study spent mushroom compost extract of Pleurotus ostreatus (SMCE) was evaluated for its potential in bioremediation against Endosulfan in different microcosms. Activities of Laccase and MnP were also monitored to observe their possible role in this process. The SMCE alone $\left(\mathrm{M}_{1}\right)$ and SMCE with $\mathrm{H}_{2} \mathrm{O}_{2}\left(\mathrm{M}_{2}\right)$ exhibited no significant difference in reduction of $\alpha$ - and $\beta$-Endosulfan. This suggested that stimulation of ligninolytic enzymes, Laccase and Manganese peroxidase, after addition of $\mathrm{H}_{2} \mathrm{O}_{2}$ as observed by monitoring their activity had no effect on bioremediation of this pesticide. In soil microcosms however, there was a significantly higher reduction in $\mathrm{M}_{4}\left(\mathrm{H}_{2} \mathrm{O}_{2}+\right.$ SMCE) than $\mathrm{M}_{3}$ (SMCE) suggesting that SCME not only served as source of complex enzymes but also as carbon resulting in enhanced soil indigenous microbial communities and enzymes. Under the effect of $\mathrm{H}_{2} \mathrm{O}_{2}$, certain enzyme complexes either already present in soil or introduced after SMCE addition worked in symbiotic way and resulted in higher reduction. Endosulfan sulfate was detected in all microcosms expect Endosulfan Sulfate while Endosulfan lactone was only formed in $\mathrm{M}_{3}$ and $\mathrm{M}_{4}$.
\end{abstract}

Keywords: enzymatic bioremediation, spent mushroom compost, Endosulfan, soil, microcosms

\section{Introduction}

In the past few decades use of agrochemical residues increased in the ecosystem, causing momentous contamination in many terrestrial regions resulting in poisoning of human foods (Carvalho, 2017). Organochlorine pesticides (OCPs), group of such agrochemicals are also known for high persistence and non target toxicity within ecosystem at each level of food chain (Jayaraj et al., 2016). Because of their bio accumulative nature (Zhang et al., 2015) these are among the priority pollutants according to the Stockholm convention (Tsai, 2010). Despite the ban, indiscriminate use of OCPs for farm activities is still in practice (Yadav et al., 2017). Majority of these 
pesticides are located in overpopulated tropic and sub tropic areas (Wang et al., 2016; Buah-Kwofie and Humphries, 2017) but due to atmospheric circulation, they could be transported to areas where there was no history of their usage and production (Hageman et al., 2015).

Endosulfan, an important OCP, was also banned but its residues are still a bio concern in the ecosystem (Hu et al., 2014; Lal et al., 2010; Barcelo-Quintal et al., 2008; Wang et al., 2016) and because of their widespread nature they are considered nowadays a "global pollutant" and a challenge for land management agencies. The conventional methods for remediation of contaminated soil are costly and not ecofriendly (Ojuederie and Babalola, 2017), an alternative effective approach for detoxification of Endosulfan in the soil is an environmental responsibility. Few such methods include bio-augmentation, intrinsic bioremediation and phytoremediation (Singh and Singh, 2017) was investigated in the past and found the best because of their effectiveness in decontaminations (Uqab et al., 2016) and considered as the major pathway for Endosulfan degradation in soil (Ozdal et al., 2017).

One of the Endosulfan bioremediation approach is exploiting white rot fungi (WRF) for its treatment (Kamei et al., 2011). However, direct application of them in the soil under actual treatment is not a viable option because WRF are not stable in the soil under physiological stress due to extreme environmental conditions (Hatakka, 1994; Crawford and Ramachandra, 1993). The resultant end product of certain WRF is spent mushroom compost (SMC) which is left after production of fruiting bodies. Application of farmyard waste (Fogarty and Tuovinen, 1991) and other solid composts have got attention in the past for biodegradation of various OCPs including Endosulfan (Mukherjee, 2012; Al-Hassan et al., 2004). Application of organic wastes (solid and liquid form) alter the physicochemical behavior of pesticides in the soils (adsorptiondesorption, mobility, degradation, etc.) and also has positive effects on soil quality (Marín-Benito et al., 2016). However, relatively long microbial lag phases tend to increase contaminant sorption within soil microspores (Manilal and Alexander, 1991).

In the past SMC of Pleurotus was used for treatment of polycyclic aromatic hydrocarbon ( $\mathrm{Li}$ et al., 2010), biocide/fungicide (Juárez et al., 2011), synthetic and textile dyes (Papinutti and Forchiassin, 2010) and many other pollutants (Cole, 1998; Marín-Benito et al., 2016) because of its ability to tolerate and/or detoxify pesticides of complex nature (Ellouze and Sayadi, 2016) at high concentrations. SMC Extract (SMCE) contains variety of immobilized enzymes including Cellulose-degrading enzymes, xylin-degrading enzymes and lignin degrading enzymes (Nakajima et al., 2018) which were reported to be involved in process of bioremediation (Lim et al., 2013; Ko et al., 2005; Karigar and Rao, 2011). These enzymes are viable under stress condition which make SMC the best candidate to treat the contaminants under field conditions. Application of WRF directly at field level has not had much success due to the difficulties in growth to adequate biomass in soil (Chirnside et al., 2011). For bioremediation of certain pollutants in soil, production of sufficient biomass and acclimatization of that particular fungus is essential (Husaini, 2014). Extracellular ligninolytic enzymes of these WRF fungi do not lose their identity in soil and can be successfully used as bio remedial agent for treatment of herbicides Application of WRF directly at field level has not had much success due to the difficulties in growth to adequate biomass in soil (Chirnside et al., 2011). For bioremediation of certain pollutants in soil, production of sufficient biomass and acclimatization of that particular fungus is essential (Husaini, 2014). Extracellular ligninolytic enzymes of these WRF 
fungi do not lose their identity in soil and can be successfully used as bio remedial agent for treatment of herbicides (Chirnside et al., 2011).

This showed that there is a clear gap in knowledge regarding role of ligninolytic enzymes in effluent treatment. In the present study we sought to determine the role of ligninolytic enzyme extract obtained from SMC of Pleurotus ostreatus in the treatment of Endosulfan. For this purpose, we tried to address this gap by extracting and concentrating two ligninolytic enzymes from SMC of this fungus, Laccase and Manganese peroxidase $(\mathrm{MnP})$ and studied their potential for detoxification of this pesticide under incubation studies of soils using biometric flasks.

\section{Materials and methods}

\section{Chemicals/gases}

Endosulfan (analytical grade) was purchased from Sigma Aldrich (St. Louis, Missouri) (99.99\%). Pestanal ${ }^{\circledR}$ grade organic solvents including n-hexane, acetonitrile and acetic acid were used. The salts used for extraction of Endosulfan from samples e.g., magnesium Sulfate (anhydrous) and sodium acetate trihydrate $\left(\mathrm{NaCH}_{3} \mathrm{COO} .3 \mathrm{H}_{2} \mathrm{O}\right)$ were also of Analytical grade. Gases used for GC-MS (helium) and for GC- $\mu$ ECD (nitrogen) were $99.999 \%$ pure. All the other chemicals used to monitor the activity of enzymes, Carbon dioxide, physicochemical properties of soil and SMC were of laboratory grade. Millipore water was used for measuring physicochemical properties of soil and SMC and extraction of pesticides.

\section{Physicochemical properties of soil}

Fine loamy Soil obtained from Organic Farming Orchard, National Agriculture Research Centre, Islamabad, Pakistan $\left(73.127855^{\circ} \mathrm{E}\right.$, and latitude $\left.33.666042^{\circ} \mathrm{N}\right)$ with no history of OCPs (established by GC- $\mu \mathrm{ECD}$ analysis) was used for this study. The physical and chemical parameters e.g., particle size distribution (sand, silt and clay), $\mathrm{pH}$, electrical conductivity (EC), total organic carbon, total nitrogen, Calcium Carbonate content $\left(\mathrm{CaCO}_{3}\right)$ were measured by using standard procedures (Sparks et al.,1996; Dane et al., 2002) and results are given in Table 1. The basic characterization of soil and incubation studies were carried out in Soil Environment laboratory, Land resources research Institute, National Agricultural research center, Islamabad, Pakistan.

Table 1. Physicochemical properties of soil used in experiment $(n=5)$

\begin{tabular}{c|c}
\hline Properties (units) of soil & \\
\hline $\mathrm{pH}$ & 8.04 \\
$\mathrm{EC}(\mu \mathrm{S} / \mathrm{cm})$ & 2.49 \\
Organic Matter $(\%)$ & 0.901 \\
Total $\mathrm{CaCO}_{3}(\%)$ & 3.15 \\
\hline Texture class (sandy clay loam) & \\
\hline Clay $(\%)$ & 25.32 \\
Silt (\%) & 22.55 \\
Sand $(\%)$ & 52.53 \\
\hline
\end{tabular}




\section{Concentrated SMC extract (SMCE)}

Culture of P. ostreatus (WC-814) were shipped from Mushroom Research Program, Pennsylvania State University.

(i) Preparation of Spawn: Spawn was prepared by placing mycelium of above mentioned fungus onto steam-sterilized wheat grains (Cooled) at $22{ }^{\circ} \mathrm{C}$. When the mycelium was completely grown through all the grain, the grain/mycelium mixture (known as spawn) was used to "seed" mushroom compost. (ii) Preparation of SMC: It was prepared by using $2 \mathrm{~kg}$ well chopped wheat straw, $1 / 2 \mathrm{~kg}$ of wheat bran and small quantity of calcium hydroxide $\mathrm{Ca}(\mathrm{OH})_{2}$ in polyethylene bag. The bags were entirely sterilized by autoclaving at $121^{\circ} \mathrm{C}$ and $15 \mathrm{psi}$ for $50 \mathrm{~min}$. On cooling the spawn $(10 \mathrm{~g})$ was added in each bag and was allowed to yield fruiting bodies. At the end of generation of fruiting bodies, the product leftover was called as SMC. (iii) Preparation of SMCE: $3 \mathrm{~g}$ fresh SMC Fresh (ground and sieve through $10 \mathrm{~mm}$ ) was taken in an Erlenmeyer flask and then $30 \mathrm{~mL}$ sodium tartrate buffer $(\mathrm{pH}=5.2)$ was added. The suspension was shaken at $22^{\circ} \mathrm{C}$ and $150 \mathrm{rpm}$ for $2 \mathrm{~h}$ as described by Lang et al. (1998) with slight modifications. Then, contents were extracted by squeezing manually using mira cloth and fluids was centrifuged (make and model) at the rate of $10,000 \times \mathrm{g}$ for 30 min (Márquez Araque et al., 2007). (iv) Concentration of SMCE: It was concentrated using Vivaspin 20 (10 kDa cutoff) - a disposable ultra-filtration device with twin vertical membrane for unparalleled speed in Centrifuge at the speed of $2800 \times \mathrm{g}$.

\section{Physicochemical properties of SMC}

Physicochemical properties of concentrated extracellular SMCE e.g., pH (707 soil/compost $\mathrm{pH}$ meters), total organic carbon (TOC) (Tandon, 2005), protein and C: $\mathrm{N}$ ratio were determined using standard methods already used by Marín-Benito et al. (2016). Total N in SMC was determined by Kjeldahl method (Helrich, 1995) (Table 2).

Table 2. Physicochemical properties of concentrated spent mushroom compost extract used in experiment $(n=5)$

\begin{tabular}{c|c|c}
\hline Sr. No & \multicolumn{2}{|c}{ Properties (units) } \\
\hline 1 & $\mathrm{pH}$ & 7.25 \\
2 & Total carbon (\%) & 16.62 \\
3 & Total nitrogen (\%) & 1.036 \\
4 & Total protein (\%) & 8.19 \\
5 & Organic matter (\%) & 30.66 \\
6 & C:N ratio & $15: 1$ \\
\hline
\end{tabular}

\section{Ligninolytic enzymes activity of SMCE}

UV-VIS (Perkin-Elmer-Lambda-25) at different wavelengths was used to monitor ligninolytic enzymes activities of concentrated extract with/without additions of hydrogen peroxide $\left(\mathrm{H}_{2} \mathrm{O}_{2}\right)$ periodically (Table 3). Activities of manganese peroxidase $(\mathrm{MnP})$ were determined by O-dianisidine $\left(\mathrm{C}_{14} \mathrm{H}_{16} \mathrm{~N}_{2} \mathrm{O}_{2}\right)$ oxidation at $460 \mathrm{~nm}$ (molar extinction coefficient $=29,400 \mathrm{M}^{-1} \mathrm{~cm}^{-1}$ ) (Paszczyński et al., 1988). Similarly, Laccase activities were monitored using 2, 2'-azino-di-[3-ethyl-benzo-thiazolin-sulphonate (ABTS) as a substrate while activities of Lignin Peroxidase (LiP) were measured by 
oxidation of Veratryl Alcohol $\left(\mathrm{C}_{9} \mathrm{H}_{12} \mathrm{O}_{3}\right)$ to veratraldehyde $\left(\mathrm{C}_{9} \mathrm{H}_{10} \mathrm{O}_{3}\right)$ at $310 \mathrm{~nm}$ (Tien and Kirk, 1988).

Table 3. Ligninolytic enzyme activities of various microcosms during four-week incubation studies $(n=3)$

\begin{tabular}{|c|c|c|c|c|c|c|}
\hline \multirow{3}{*}{ Days } & \multicolumn{6}{|c|}{ Microcosms containing Endosulfan } \\
\hline & \multicolumn{2}{|c|}{$\mathrm{M}_{1}^{* *}\left(\mathrm{SMCE}^{*}+\mathrm{H}_{2} \mathrm{O}_{2}\right)$} & \multicolumn{2}{|c|}{$\mathrm{M}_{2}^{* *}$ (SMCE only) } & \multicolumn{2}{|c|}{ Control 1 and 2} \\
\hline & Laccase & MnP & Lac & MnP & Lac & MnP \\
\hline 0 & $32 \pm 2.3$ & $18 \pm 1.4$ & $22 \pm 1.4$ & $8 \pm 1.1$ & ND & ND \\
\hline 7 & $25 \pm 1.3$ & $12 \pm 3.5$ & $17 \pm 2.2$ & $5 \pm 3.1$ & ND & ND \\
\hline 14 & $16 \pm 2.4$ & $7 \pm 2.4$ & $13 \pm 3.1$ & $2 \pm 1.5$ & ND & ND \\
\hline 21 & $9 \pm 2.0$ & $4 \pm 1.3$ & $7 \pm 2.2$ & $0 \pm 0$ & ND & ND \\
\hline 28 & $3 \pm 1.5$ & $1 \pm 2.9$ & $1 \pm 1.7$ & $0 \pm 0$ & ND & ND \\
\hline
\end{tabular}

*SMCE: spent mushroom compost extract, $\mathrm{M}_{1}$ and $\mathrm{M}_{2}$ mean microcosm 1 and 2

\section{Experimental set up for biodegradation of OCPs}

Using concentrated aqueous SMC extract (SMCE)

Concentrated SPME was used as bio remedial to treat Endosulfan. Erlenmeyer flasks $(250 \mathrm{ml})$ were autoclaved twice and were spiked with Endosulfan at the final concentration of $25 \mathrm{mgL}^{-1}$. Microcosms were treated in the following manner

a) Microcosm 1( $\left.\mathrm{M}_{1}\right): 10 \mathrm{~mL}$ of the collected concentrated SMCE

b) Microcosm 2(M $\left.\mathrm{M}_{2}\right): 10 \mathrm{~mL}$ of the SMCE and $800 \mu \mathrm{l}$ of $\mathrm{H}_{2} \mathrm{O}_{2}(0.4 \mathrm{mM})$

c) Control 1( $\left.\mathrm{C}_{1}\right): 10 \mathrm{~mL}$ of boiled SMCE (to denature all the enzymes present in it). This control was used as associated control of $\mathrm{M}_{1}$

d) Control 2( $\left.\mathrm{C}_{2}\right): 10 \mathrm{~mL}$ of boiled SMCE and $800 \mu \mathrm{L}$ of $\mathrm{H}_{2} \mathrm{O}_{2}(0.4 \mathrm{mM})$. This control was used as associated control of $\mathrm{M}_{2}$.

\section{Application of concentrated SMCE in soil}

Biometric flasks $(250 \mathrm{~mL})$ (Bellco, Glass Inc., Vineland, NJ) were used for preparation of soil microcosms while SMCE extract was used as bio remedial for Endosulfan decontamination. The main body of biometric flasks consisted of soil $(25 \mathrm{~g})$ spiked Endosulfan at final concentration of $25 \mathrm{mgkg}^{-1}$. During the experiment, side arm of flasks was filled with $50 \mathrm{ml}$ solution of $0.4 \mathrm{~N} \mathrm{NaOH}\left[\mathrm{CO}_{2}\right.$-free Double distilled water (DDW)] and was used as trap to monitor $\mathrm{CO}_{2}$. Following five treatments were applied in main body of flasks already contaminated with mixture of Endosulfan isomers to access role of SMCE, derived from $P$. ostreatus in the process of bioremediation:

1. Microcosm 3(M $\left.\mathrm{M}_{3}\right)$ : Fresh soil $(20 \mathrm{~g})$ was amended with $10 \mathrm{~mL}$ of freshly prepared SMCE.

2. Microcosm 4(M $\left.\mathrm{M}_{4}\right): 20 \mathrm{~g}$ fresh soil $+10 \mathrm{~mL} \mathrm{SMCE}+800 \mu \mathrm{L} \mathrm{H}_{2} \mathrm{O}_{2}(0.4 \mathrm{mM})$.

3. Control 3($\left(\mathrm{C}_{3}\right)$ : Associated control of $\mathrm{M}_{3}: 20 \mathrm{~g}$ soil+ denatured SMCE (10 ml).

4. Control 4( $\left.\mathrm{C}_{4}\right)$ : Associated control of $\mathrm{M}_{4}: 20 \mathrm{~g}$ soil + denatured SMCE $+\mathrm{H}_{2} \mathrm{O}_{2}\left(800 \mu \mathrm{L} \mathrm{H} \mathrm{H}_{2} \mathrm{O}_{2}(0.4 \mathrm{mM})\right.$ to monitor role of $\mathrm{H}_{2} \mathrm{O}_{2}$ activated sterilized SMCE in contaminated soil. 
5. Microcosm 5(M5) (abiotic control): $20 \mathrm{~g}$ double autoclaved soil + denatured SMCE to find role of other soil inhabitant microbes in biodegradation.

During both the experiment flasks were incubated at $22{ }^{\circ} \mathrm{C}$ for 28 days. During the experiment, moisture level $(60 \%)$ was maintained by taping DDW. The flasks were weighed and corrected for evaporative water loss by addition of sterile water prior to sampling at each time series. At the end of experiment, the samples were immediately put in boiling water and subsequently mixing with $10 \mathrm{~mL}$ acetonitrile to stop enzymes activity. All the experiment was conducted with three replicate flaks to improve the confidence of results. Required number of microcosms were taken off (sampled as whole) after each seven days till the end of experiment.

\section{Measurement of carbon dioxide $\left(\mathrm{CO}_{2}\right)$}

Sodium hydroxide $(\mathrm{NaOH})$ present in trap of biometric flasks was used to monitor $\mathrm{CO}_{2}$ production using traditional acid titration method (Paul et al., 1999). Acid/base titration was done (at the same time intervals) for measurement of total carbon dioxide evolved. Samples were taken at day $0,7,14,21$ and 28 and production of $\mathrm{CO}_{2}$ was monitored. The total amount of $\mathrm{CO}_{2}$ evolved from the treatment bio meters was used as measure of rate of mineralization.

\section{Extraction of OCPs from microcosms and analysis}

\section{Extraction from SPME microcosm}

SMCE microcosms contents were transferred to centrifuge tubes and thoroughly mixed for 1 min using vortex mixer (Velp scientific centre, Bohemia, NY). After addition of $10 \mathrm{~mL}$ of acetone: water $(1: 3, \mathrm{v} / \mathrm{v})$, the content was transferred to separating funnel (Pyrex ${ }^{\circledR}$ Squibb, Corning, New York), acetonitrile $(2 \mathrm{~mL})$ added and shaken vigorously for $5 \mathrm{~min}$ manually followed by addition of petroleum ether $(2.0 \mathrm{~mL})$. Aqueous portion was discarded and organic layer was dried with $1 \mathrm{~g}$ Sodium sulfate $\left(\mathrm{NaSO}_{4}\right)$ (anhydrous) and gauged at $2 \mathrm{~mL}$ using rotary evaporator (BuchiRotavapour.R-210) (Hernandez-Rodriguez et al., 2006)

\section{Extraction from soil microcosm}

Quick, easy, cheap, effective, rugged, and safe (QuEChERS) extraction method (with cleanup) (Boes et al., 2015) was used for extraction of selected OCP from soil with slight modifications. After hydration of samples $(10 \mathrm{~g})$ for $30 \mathrm{~min}$ using water $(10 \mathrm{~mL})$ and acidified acetonitrile $(10 \mathrm{~mL})(99: 1 \mathrm{v} / \mathrm{v})$ in $50 \mathrm{~mL}$ tube, the contents were mixed for 5 min using vortex mixer (Velp scientific centre, Bohemia, NY) and dried and buffered by adding $4.0 \mathrm{~g}$ magnesium sulfate (anhydrous) $\left(\mathrm{MgSO}_{4}\right), 1.0 \mathrm{~g}$ sodium chloride $(\mathrm{NaCl})$, $1.0 \mathrm{~g}$ trisodium citrate dehydrate $\left(\mathrm{C}_{6} \mathrm{H}_{5} \mathrm{Na}_{3} \mathrm{O}_{7} .2 \mathrm{H}_{2} \mathrm{O}\right)$ and $0.5 \mathrm{~g}$ disodium hydrogen citrate sesquihydrate $\left(\mathrm{C}_{6} \mathrm{H}_{8} \mathrm{Na}_{2} \mathrm{O}_{8}\right)$. Centrifugation was done at $5000 \times \mathrm{g}$ for $5 \mathrm{~min}$. After separation of acetonitrile layer, it was concentrated to $5 \mathrm{ml}$ and was later mixed with water $(2 \mathrm{~mL})$ and $\mathrm{n}$-hexane $(10 \mathrm{~mL})$ and swirled for $1 \mathrm{~min}$. After $2 \mathrm{~min}$, an aliquot of $9 \mathrm{ml}$ of the upper $\mathrm{n}$-hexane layer was collected and reduced again to $1.4 \mathrm{~mL}$ in an amber glass vials and stored at $-20^{\circ} \mathrm{C}$. Analysis of Endosulfan in extracted samples was done using Gas Chromatography (7890B Agilent) equipped with micro-electron capture detector $(\mathrm{G} 3440 \mathrm{~B})$. HP-5(30 $\mathrm{m} \times 0.25 \mu \mathrm{m}$ I.D $\times 0.320 \mathrm{~mm})$ capillary column was used. 
Gas chromatography (GC- 7890B Agilent) mass spectrometry (MSD-5977A Agilent) with column DB-5 Ultra inert $(30 \mathrm{~m} \times 0.25 \mathrm{~mm}$ i.d $\times 0.25 \mathrm{~lm})$. Summary of conditions is shown in Table 4. Matching library used was Retention time lock Pesticides and endocrine disruptor MS Library (RTLPEST3.L). Recovery of Endosulfan (Table 5) was in accordance with acceptability criteria set in SANCO's (2017).

Table 4. Conditions for gas chromatography analysis using electron capture detector and mass spectrometer detector

\begin{tabular}{|c|c|c|}
\hline \multicolumn{3}{|c|}{ Conditions } \\
\hline & GC-MSD & GC- $\mu$ ECD \\
\hline Column & $\begin{array}{l}\text { DB-5 Ultra inert }\left(-60{ }^{\circ} \mathrm{C} \text { to } 325^{\circ} \mathrm{C}\left(350^{\circ} \mathrm{C}\right)\right. \\
(30 \mathrm{~m} \times 0.25 \mathrm{~mm} \text { i.d } \times 0.25 \mu \mathrm{m})\end{array}$ & $\begin{array}{c}\text { HP-5 }(30 \mathrm{~m} \times 0.25 \mu \mathrm{m} \text { i.d } \times \\
0.320 \mathrm{~mm})\end{array}$ \\
\hline Injector temperature & $250^{\circ} \mathrm{C}$ & $225^{\circ} \mathrm{C}$ \\
\hline $\begin{array}{l}\text { Carrier gas/purity/flow } \\
\text { rate }\end{array}$ & Helium gas/99.999\%/2 $\mathrm{ml} \mathrm{min}^{-1}$ & Nitrogen/99.999\%/2 $\mathrm{ml} \mathrm{min}^{-1}$ \\
\hline Detector temperature & $280^{\circ} \mathrm{C}$ & $280^{\circ} \mathrm{C}$ \\
\hline $\begin{array}{l}\text { Oven temperature } \\
\text { ramping }\end{array}$ & $\begin{array}{l}\text { Initial oven temperature } 60{ }^{\circ} \mathrm{C}(0.5 \mathrm{~min}) \text { was } \\
\text { increased at } 20^{\circ} \mathrm{C} \min ^{-1} \text { to } 170{ }^{\circ} \mathrm{C}(3 \mathrm{~min} \\
\text { hold }) \text {. Later on, it was increased at rate of } 5{ }^{\circ} \mathrm{C} \\
\mathrm{min}^{-1} \text { to } 295^{\circ} \mathrm{C}(44 \mathrm{~min}) \text { to allow all the } \\
\text { metabolites to elute from column }\end{array}$ & $\begin{array}{l}\text { Initial oven temperature } 80 \\
{ }^{\circ} \mathrm{C}(0.5 \mathrm{~min}) \text { increased at } \\
10{ }^{\circ} \mathrm{C} \mathrm{min}{ }^{-1} \text { to } 180{ }^{\circ} \mathrm{C} \text { (held } \\
\text { for } 10) \text {, then increased at } \\
15{ }^{\circ} \mathrm{C} \mathrm{min}-1 \text { to } 250{ }^{\circ} \mathrm{C} \text { and } \\
\text { finally held for } 10 \mathrm{~min}\end{array}$ \\
\hline
\end{tabular}

Table 5. Recovery of Endosulfan isomers by selected extraction method $(n=5)$

\begin{tabular}{c|c|c|c|c}
\hline \multirow{2}{*}{ Compound } & \multicolumn{2}{|c|}{ SMCE } & \multicolumn{2}{c}{ Soil spiked with SMCE } \\
\cline { 2 - 5 } & Recovery (\%) & RSD (\%) & Recovery (\%) & RSD (\%) \\
\hline \multirow{2}{*}{$\alpha$-Endosulfan } & 91.00 & 2.19 & 88.59 & 3.18 \\
B-Endosulfan & 99.22 & 0.59 & 96.73 & 0.78 \\
\hline
\end{tabular}

\section{Kinetic studies and statistical analysis}

Simple first-order kinetics (SFO) was used found the most fitted kinetic equation for the set of experiments. The reduction in extractable amount of Endosulfan from the artificially spiked soil was calculated using Equation 1 (Yang et al., 2014)

$$
\ln C=a+K_{1} t
$$

where $\ln C$ is natural logarithm of concentration, $t$ is time given to compound for degradation and $K_{l}$ is first order rate constant.

Half-life (DT50) was calculated by Equation 2:

$$
D T_{50}=t_{1 / 2}=\frac{0.693}{k 1}
$$

For $\mathrm{DT}_{50}$ and $\mathrm{DT}_{90}$ calculations, a computer program R (version 3.0.3) with the kinfit software package was used. The best fitted SFO (simple first-order kinetics) was used. The data was statistically analyzed (analysis of variance) using complete randomized 
design with two factors (treatments and times) at $\alpha=0.05$ by Statistix 8.1 (Analytical Software, USA) computer program.

\section{Results and discussion}

This study was designed to find the potential of ligninolytic enzymes extract obtained from SMC to treat this pesticide in soil. In order to make the enzymatic effect clear, concentration of the enzyme and treatment of the microcosms with or without $\mathrm{H}_{2} \mathrm{O}_{2}$ was done. SMC has many immobilized enzymes that could serve as bio remedial agent (Valentin et al., 2010). Therefore, some researchers applied SMC directly in soil to treat contaminants (Marín-Benito et al., 2016). Direct application is beneficial because it acts as the substrate to change the bioavailability and immobilization of pesticides in the soil. However, while studying the role of ligninolytic enzymes in bioremediation, direct use of SMC is also a big problem because of adsorption of pesticides onto fungal biomass and compost which hinders true revelations. Therefore, extraction of enzymes from SMC and their application in soil is another option.

\section{Bioremediation of Endosulfan using only SMCE}

After application of Endosulfan in flask, microcosms were treated with SMCE and bioremediation of both the isomers of this pesticide was studied. In $\mathrm{M}_{1}$ where $\mathrm{H}_{2} \mathrm{O}_{2}$ was added in microcosm to stimulate the effect of enzyme in SMCE, 24.99\% of applied $\alpha$ Endosulfan was reduced at the end of first week of incubation. At the end of $4^{\text {th }}$ week, $58 \%$ of applied extractable $\alpha$-Endosulfan was removed. However, $56.85 \%$ of removal was observed in $\mathrm{M}_{2}$, where no $\mathrm{H}_{2} \mathrm{O}_{2}$ was added. It showed addition of $\mathrm{H}_{2} \mathrm{O}_{2}$ did not play any substantial role in reduction of applied $\alpha$-Endosulfan as there was no significant difference $(\alpha=0.05, \mathrm{p}<0.01)$ in both above mentioned microcosms, $\mathrm{M}_{1}$ and $\mathrm{M}_{2}$ (Table 6).

Table 6. Bioremediation of Endosulfan under different microcosms to access the role of extracellular enzyme extract, where $M_{1}$ and $M_{2}$ are Microcosm 1 and 2 , while $C 1$ and $C 2$ are their associated controls $(\alpha=0.05 ; p<0.01)$

\begin{tabular}{|c|c|c|c|c|c|c|c|c|c|c|}
\hline \multirow{3}{*}{ Days } & \multicolumn{10}{|c|}{ Relative reduction $(\%)$ of applied concentration } \\
\hline & \multicolumn{5}{|c|}{ a-Endosulfan } & \multicolumn{5}{|c|}{$\beta$-Endosulfan } \\
\hline & $\mathbf{M}_{1}$ & $\mathbf{M}_{2}$ & $\mathrm{C}_{1}$ & $\mathrm{C}_{2}$ & Means & $\mathbf{M}_{1}$ & $\mathbf{M}_{2}$ & $\mathrm{C}_{1}$ & $\mathrm{C}_{2}$ & Means \\
\hline 0 & 0.00 & 0.00 & 0.00 & 0.00 & $0^{\mathrm{e}}$ & 0 & 0.00 & 0.00 & 0.00 & $0^{\mathrm{e}}$ \\
\hline 7 & 24.99 & 17.73 & 6.68 & 3.20 & $13.15^{\mathrm{d}}$ & 7.64 & 6.85 & 2.85 & 1.25 & $4.65^{\mathrm{d}}$ \\
\hline 14 & 40.22 & 43.37 & 8.35 & 6.61 & $24.64^{\mathrm{c}}$ & 14.65 & 10.57 & 3.64 & 2.99 & $7.96^{\mathrm{c}}$ \\
\hline 21 & 48.25 & 50.05 & 10.93 & 9.01 & $29.56^{\mathrm{b}}$ & 18.42 & 16.76 & 4.96 & 3.46 & $10.9^{\mathrm{b}}$ \\
\hline 28 & 58.00 & 56.85 & 12.36 & 10.25 & $34.37^{\mathrm{a}}$ & 20.87 & 21.49 & 5.49 & 4.59 & $13.11^{\mathrm{a}}$ \\
\hline Means & $34.29^{\mathrm{a}}$ & $33.6^{\mathrm{a}}$ & $7.66^{\mathrm{b}}$ & $5.184^{b}$ & 20.34 & $12.32^{\mathrm{a}}$ & $11.13^{\mathrm{a}}$ & $3.39^{\mathrm{b}}$ & $2.46^{\mathrm{b}}$ & 7.324 \\
\hline
\end{tabular}

$\alpha$-Endosulfan: LSD for Days 2.69; LSD for treatments 3.21

$\beta$-Endosulfan: LSD for Days 1.22; LSD for treatments 1.46

The calculated rate of dissipation using SFO kinetics was not substantially different in both the microcosms which resulted in $\mathrm{DT}_{50}$ equal to 22 days and 21 days for $\mathrm{M}_{1}$ and $\mathrm{M}_{2}$ respectively (Table 7). $\mathrm{C}_{1}$ and $\mathrm{C}_{2}$ which were the associated control of $\mathrm{M}_{1}$ and $\mathrm{M}_{2}$, 
showed the reduction of only $12.36 \%$ and $10.25 \%$ of applied $\alpha$-Endosulfan, respectively. Ultimate $\mathrm{DT}_{50}$ calculated for $\mathrm{C}_{1}$ was 154 days $\left(\mathrm{K}_{1}=0.0045\right)$ while under $\mathrm{C}_{2}$ it was 173 days $\left(\mathrm{K}_{1}=0.004\right)$. However, there were a significant difference between each microcosm and their associated controls (Table 6). In the past, it was reported that presence of $\mathrm{H}_{2} \mathrm{O}_{2}$ in ligninolytic system is responsible for faster bioremediation or decolonization (Vyas and Molitoris, 1995; Eichlerová et al., 2006). However, in this case, addition of $\mathrm{H}_{2} \mathrm{O}_{2}$ did not pose any effect on reduction of $\mathrm{M}_{2}$ than $\mathrm{M}_{1}$ where no $\mathrm{H}_{2} \mathrm{O}_{2}$ was added.

Table 7. Kinetic of dissipation of Endosulfan in spent mushroom compost extract using simple first order kinetic model

\begin{tabular}{c|c|c|c|c|c}
\hline \multirow{2}{*}{ Experimental microcosm } & \multicolumn{5}{|c}{$\boldsymbol{\alpha}$-Endosulfan } \\
\cline { 2 - 6 } & Kinetic equation & $\mathbf{K}_{\mathbf{1}}$ & $\mathbf{D T}_{\mathbf{5 0}}$ & $\mathbf{D T}_{\mathbf{9 0}}$ & $\mathbf{R}^{\mathbf{2}}$ \\
\hline $\mathrm{M}_{1}$ & $\mathrm{LnC}=4.56-0.0318 \mathrm{t}$ & 0.0318 & 21.80 & 72.40 & 0.99 \\
$\mathrm{M}_{2}$ & $\mathrm{LnC}=4.58-0.033 \mathrm{t}$ & 0.033 & 21.00 & 69.80 & 0.97 \\
$\mathrm{C}_{1}$ & $\mathrm{LnC}=4.59-0.0045 \mathrm{t}$ & 0.0045 & 154.03 & 511.69 & 0.91 \\
$\mathrm{C}_{2}$ & $\mathrm{LnC}=4.60-0.004 \mathrm{t}$ & 0.004 & 173.29 & 575.65 & 0.98 \\
\hline \multirow{5}{*}{ Experimental microcosm } & \multicolumn{5}{|c}{$\boldsymbol{\beta}$-Endosulfan } \\
\cline { 2 - 6 } & Kinetic equation & $\mathbf{K}_{\mathbf{1}}$ & $\mathbf{D T}_{\mathbf{5 0}}$ & $\mathbf{D T}_{\mathbf{9 0}}$ & $\mathbf{R}^{\mathbf{2}}$ \\
\hline $\mathrm{M}_{1}$ & $\mathrm{LnC}=4.59-0.0087 \mathrm{t}$ & 0.0087 & 79.67209 & 264.665 & 0.97 \\
$\mathrm{M}_{2}$ & $\mathrm{LnC}=4.60-0.0085 \mathrm{t}$ & 0.0085 & 81.54673 & 270.8924 & 0.99 \\
$\mathrm{C}_{1}$ & $\mathrm{LnC}=4.60-0.00194 \mathrm{t}$ & 0.00194 & 357.2924 & 1186.9 & 0.91 \\
$\mathrm{C}_{2}$ & $\mathrm{LnC}=4.60-0.00167 \mathrm{t}$ & 0.00167 & 415.0582 & 1378.793 & 0.97 \\
\hline
\end{tabular}

The other isomer of Endosulfan, $\beta$-Endosulfan showed the similar reduction pattern (Table 6 ) but the rate of this reduction was about $1 / 3$ of that observed in case of $\alpha$ Endosulfan. Total removal of this isomer, during incubation period, in $\mathbf{M}_{1}$ and $\mathrm{M}_{2}$ was $20.87 \%$ and $21.49 \%$ respectively showing there was no significant difference $(\alpha=0.05$, $\mathrm{p}<0.01$ ) in bioremediation efficacy of SMCE with or without $\mathrm{H}_{2} \mathrm{O}_{2}$ (Table 6). It shows that stimulation of enzymes by adding $\mathrm{H}_{2} \mathrm{O}_{2}$ as were mentioned in another study (Chirnside et al., 2011) had no role in reduction of $\beta$-Endosulfan. DT 50 , calculated for $\mathrm{M}_{1}$ and $\mathrm{M}_{2}$ were 80 days and 82 days respectively. It also showed autoclaving to denature the SMCE was responsible for the slow rate of removal (Table 7) because it eliminated biotic factor including enzymes and microbes in associated controls.

SMCE of $P$. ostreatus was monitored for two main ligninolytic enzymes MnP and Laccase enzyme activities in all the microcosms (Table 3). Immediately after addition of $\mathrm{H}_{2} \mathrm{O}_{2}$ on day zero, the activities of both the enzymes, Laccase and MnP, were higher showing stimulatory effect of $\mathrm{H}_{2} \mathrm{O}_{2}$ on $\mathrm{M}_{1}$ (Table 3). All the activities had downward trend at each sampling time which shows that with the passage of incubation time, the enzymes activities were declined. The activities of $\mathrm{MnP}$ and Laccase in $\mathrm{M}_{2}$ where no $\mathrm{H}_{2} \mathrm{O}_{2}$ was added were lower than $\mathrm{M}_{1}$ at each time interval (Table 3). $\mathrm{M}_{1}$ showed significantly more activities of Laccase and $\mathrm{MnP}$ than $\mathrm{M}_{2}$ but there was no significant difference in reduction of both the isomers of Endosulfan. For example, a study conducted by Ulčnik et al. (2013) showed that purified laccase obtained from this fungus and other related ligninolytic enzymes were found to play no role in the process of bioremediation. Another study conducted by Purnomo et al. (2010) also showed that 
ligninolytic enzyme are not involved in the bioremediation of OCPs. Same is proved in our case.

During the course of study, oxidation occurred and only one dechlorination metabolite, Endosulfan sulfate was formed in flasks from day 7 and no other metabolite was detected on GC-MSD.

\section{Bioremediation of Endosulfan using SMCE in Soil}

For preparation of soil microcosms, biometric flasks containing soils treated with SMCE were incubated for 28 days at $22{ }^{\circ} \mathrm{C}$. $\mathrm{NaOH}$ solution was added in the side arm of biometric flask and served as trap of $\mathrm{CO}_{2}$. Application of SMCE in fresh soil $\left(\mathrm{M}_{3}\right)$ resulted in total reduction of $41.62 \%$ of applied concentration of $\alpha$-Endosulfan at the rate 0.013 days $^{-1}$. Resultantly, calculated $\mathrm{DT}_{50}$ was 51 days $\left(\mathrm{r}^{2}=0.98\right)$. Addition of $\mathrm{H}_{2} \mathrm{O}_{2}$ along with SMCE in soil $\left(\mathrm{M}_{4}\right)$ resulted in total reduction up to $47.16 \%$ while under $\mathrm{M}_{5}$ (abiotic microcosm), the reduction of $7.42 \%$ at the rate $\mathrm{K}_{1}=0.013$ days $^{-1}$ was observed which is less than both $\mathrm{M}_{3}$ and $\mathrm{M}_{4}$. Denaturation of all the biotic factors present in soil and SMCE $\left(\mathrm{M}_{5)}\right.$ resulted in least reduction of applied $\alpha$-Endosulfan (Fig. 1). There was a significant difference in reduction between $\mathrm{M}_{3}$ and $\mathrm{M}_{4}(\alpha=0.05$, $\mathrm{P}<0.01)$. Since there are various other constituents in the soil that could be stimulated by addition of $\mathrm{H}_{2} \mathrm{O}_{2}$ (not necessarily enzymes from added extract) which resulted in significant difference in amount of reduction of $\alpha$-Endosulfan in $\mathrm{M}_{4}$ than $\mathrm{M}_{3}$. The role of addition of $\mathrm{SMCE}$ in $\mathrm{M}_{3}$ and $\mathrm{M}_{4}$ in bioremediation was assessed by running associated controls $\left(\mathrm{C}_{3}\right.$ and $\left.\mathrm{C}_{4}\right)$. The reduction of $\alpha$-Endosulfan under $\mathrm{M}_{3}$ was significantly different from its associated control $\left(\mathrm{C}_{3}\right)$. Same was true for $\mathrm{M}_{4}$ and associated control.

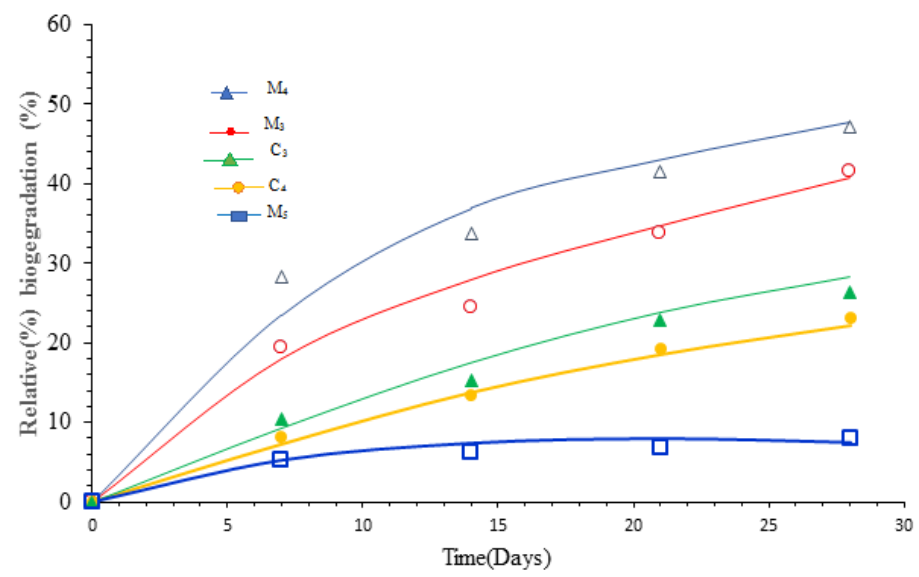

Figure 1. Relative reduction of $\alpha$-Endosulfan in soil using spent mushroom compost extract in different microcosms

Similarly, recorded reduction for $\beta$-Endosulfan under $\mathrm{M}_{3}$ was $32.40 \%$ at the rate of 0.016 day $^{-1}$ while its associated control $\mathrm{C}_{3}$ exhibited reduction equals to $20.05 \%$ at the rate of 0.0078 day $^{-1}$ (Fig. 2; Table 8). Similar pattern was observed in $\mathrm{M}_{4}$ and its associated control $\mathrm{C}_{4}$. Removal of Endosulfan isomers in $\mathrm{C}_{3}$ and $\mathrm{C}_{4}$ revealed the role of denatured SMCE as carbon source (Kodjo-Wayo, 2006) (Fig. 2). In case of abiotic control $\left(\mathrm{M}_{5}\right)$, total of $2.84 \%$ of applied $\beta$-Endosulfan was reduced. Detailed DT $\mathrm{D}_{50}$ calculated based on equation 2 and rates of all the treatments are given in Table 8. 


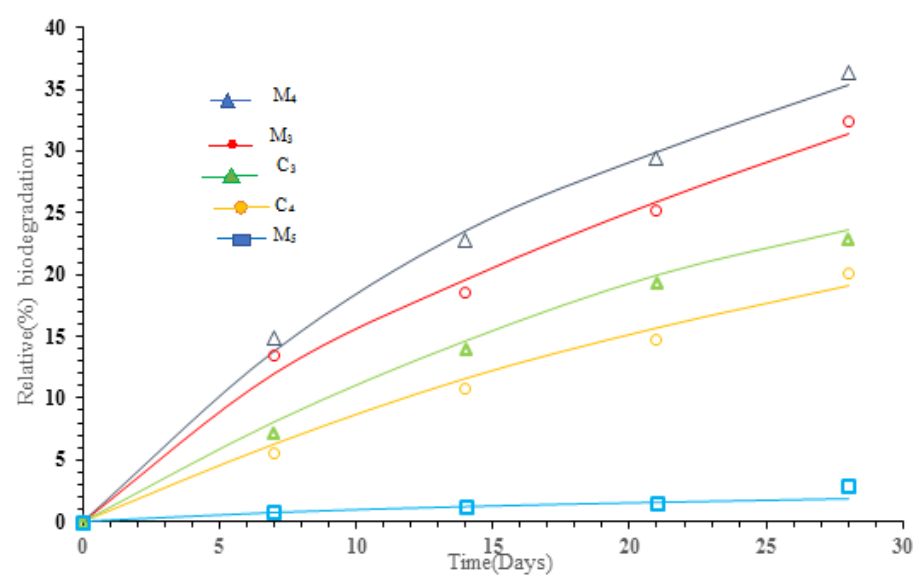

Figure 2. Relative reduction of $\beta$-Endosulfan in soil using spent mushroom compost extract

Table 8. Dissipation kinetic of Endosulfan in soil treated with SMCE using SFO model

\begin{tabular}{|c|c|c|c|c|c|c|}
\hline \multicolumn{7}{|c|}{ Kinetic studies of Endosulfan in soil using SMCE } \\
\hline Isomers & Treatments & Kinetic equation & $K_{1}\left(\right.$ day $\left.^{-1}\right)$ & $\mathrm{DT}_{50}$ & DT $_{90}$ & $\mathbf{r}^{2}$ \\
\hline \multirow{5}{*}{ 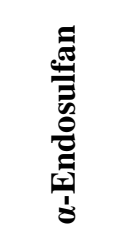 } & $\mathrm{M}_{3}$ & $4.58-0.0133 \mathrm{t}$ & 0.013 & 51.41 & 170.77 & 0.98 \\
\hline & $\mathrm{M}_{4}$ & $4.52-0.0211 \mathrm{t}$ & 0.023 & 29.65 & 98.48 & 0.91 \\
\hline & $\mathrm{C}_{3}$ & $4.60-0.009 \mathrm{t}$ & 0.009 & 73.38 & 243.75 & 0.99 \\
\hline & $\mathrm{C}_{4}$ & $4.59-0.011 \mathrm{t}$ & 0.011 & 62.45 & 207.461 & 0.98 \\
\hline & $\mathrm{M}_{5}$ & $4.59-0.002 \mathrm{t}$ & 0.002 & 259.71 & 862.74 & 0.86 \\
\hline \multirow{5}{*}{ 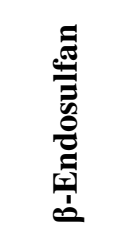 } & $\mathrm{M}_{3}$ & $4.58-0.02 \mathrm{t}$ & 0.016 & 43.2 & 143.49 & 0.98 \\
\hline & $\mathrm{M}_{4}$ & $4.57-0.0186 \mathrm{t}$ & 0.0186 & 37.08 & 123.17 & 0.97 \\
\hline & $\mathrm{C}_{3}$ & $4.60-0.007846 \mathrm{t}$ & 0.0078 & 88.33 & 293.46 & 0.97 \\
\hline & $\mathrm{C}_{4}$ & $4.58-0.0095 \mathrm{t}$ & 0.0096 & 72.48 & 240.79 & 0.99 \\
\hline & $\mathrm{M}_{5}$ & $4.61-0.00094 \mathrm{t}$ & 0.0009 & 737.75 & 2450.76 & 0.95 \\
\hline
\end{tabular}

Addition of SMCE initiates oxidative pathways and produces free radicals in soil which are removed by soil constituents and cause less reduction of toxic compounds in soil bio meters (Chirnside et al., 2011) than flasks which contained only SMCE ( $\mathrm{M}_{1}$ and $\mathrm{M}_{2}$ ). This was evident in this finding where SCME alone reduced more Endosulfan than after addition in soil. The overall reduction of both the isomers was higher in SMCE microcosms without soil $\left(\mathrm{M}_{1}\right.$ and $\left.\mathrm{M}_{2}\right)$ than the microcosms where SMCE was added in soil $\left(\mathrm{M}_{3}\right.$ and $\left.\mathrm{M}_{4}\right)$. Presence of total organic carbon (TOC) in denatured SMCE resulted in decontamination of Endosulfan in soil because of its role in increasing the indigenous population of soil microbes (Guerin, 1999; Özyer et al., 2016). In our case, SMCE was rich in organic carbon (Table 2), which further helped to enhance the population of indigenous microbes (Zhang et al., 2013) in the soil. This increase in Endosulfan removal in $\mathrm{H}_{2} \mathrm{O}_{2}$ amended microcosm of soil $\mathrm{M}_{4}$ indicated that addition of $\mathrm{H}_{2} \mathrm{O}_{2}$ in soil amended with SMCE stimulated certain soil enzymes and microbes which were not present in sole SMCE. Addition of SMCE within the soil involves couple of reactions whose nature is very difficult to explore. The less degradation of $\beta$-Endosulfan by application of SMCE in soil than $\alpha$-Endosulfan could be due to inter-conversion of the 
$\alpha$-isomer to $\beta$-Endosulfan (Rice et al., 1997; Schmidt et al., 2001) and also microbial species prefer $\alpha$-Endosulfan for degradation over $\beta$-Endosulfan (Siddique et al., 2003). The bioremediation pathways for Endosulfan after application of SMCE were built based on the time of appearance of peaks, their position and centre of mass of concentration profiles of the metabolites detected by GC-MS. In all associated controls and treatments of $\mathrm{M}_{1}$ and $\mathrm{M}_{2}$, only Endosulfan sulfate was formed (Fig. 3). Endosulfan lactone was only formed in $\mathrm{M}_{3}$ and $\mathrm{M}_{4}$ soil microcosms. Under $\mathrm{M}_{5}$, there was no appearance of any metabolites. This is possibly because of absence of process of oxidation because of un availability of microbes or enzymes. Formation of Endosulfan lactone is also in line with the findings of (Kataoka and Takagi, 2013). Other expected bioremediation products could be Endosulfan diol, Endosulfan ether, Endosulfan hydroxyether and Endosulfan monoaldehyde (Kullman and Matsumura, 1996) which were not detected during the course of this study. However, formation of Endosulfan lactone is evident for the formation of other above mentioned intermediate products and the fact that hydrolysis also occurred in the soil treated with SMCE.

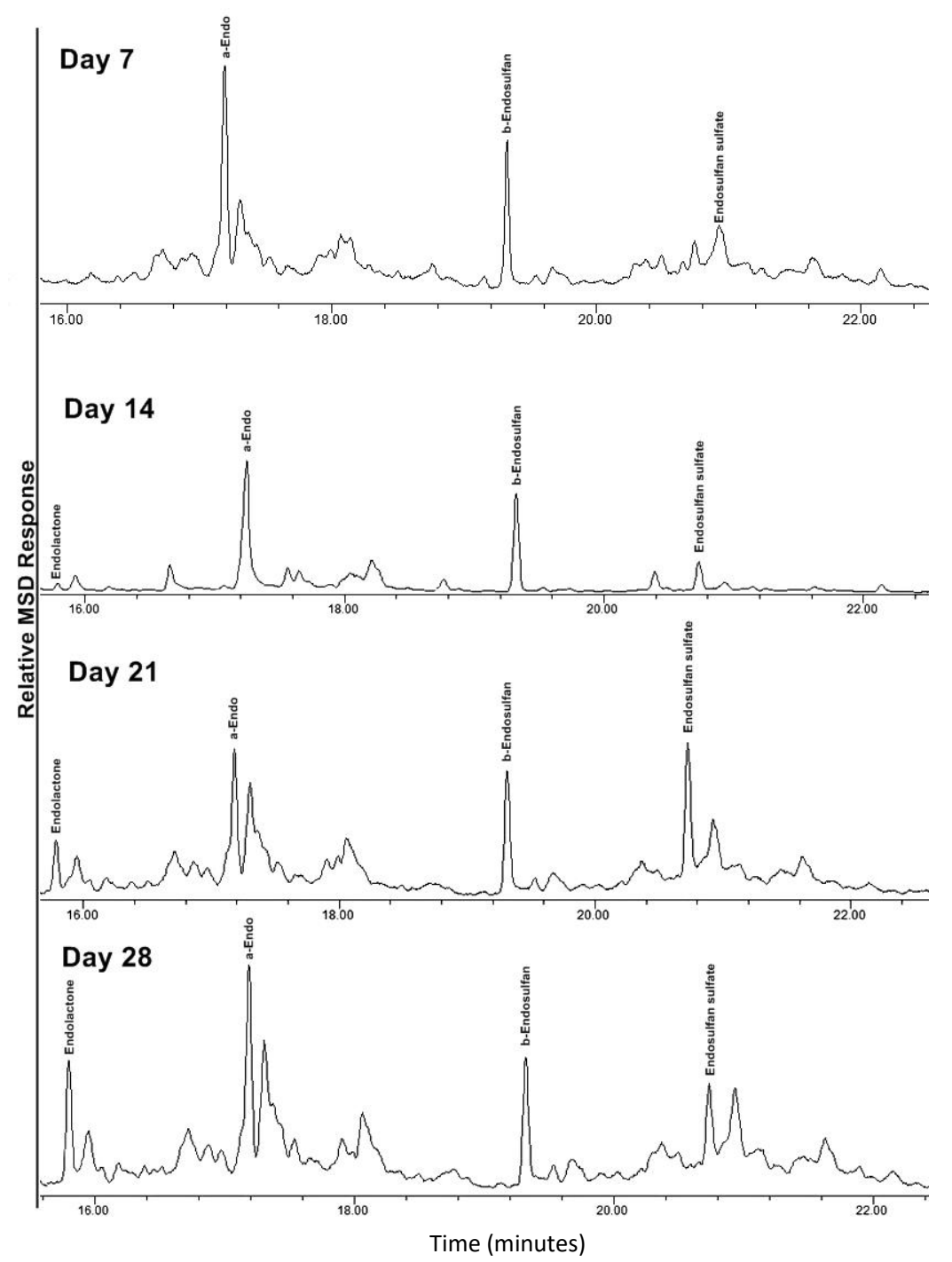

Figure 3. The metabolic products of Endosulfan detected at GC-MS after incubation of soil with spent mushroom compost extract. Formation of Endosulfan sulfate indicate oxidation while generation of Endosulfan lactone is the result of hydrolytic pathways 
Emission of carbon dioxide is a bioremediation indicator and contaminant depletion can be estimated from the amount of carbon dioxide emitted from the system (Schoefs et al., 2004). Amount of $\mathrm{CO}_{2}$ produced in spiked bio-meter flask with $\mathrm{M}_{3}$ and $\mathrm{M}_{4}$ was much more than associated controls of containing denatured SMCE (Fig. 4). Evolution of $\mathrm{CO}_{2}$ was increased exponentially as experiment progressed. The evolution of $\mathrm{CO}_{2}$ from $\mathrm{M}_{5}$ flask was the slowest of all the microcosms. The highest amount of $\mathrm{CO}_{2}$ generated was in $\mathrm{M}_{4}$. It is observed that the emission and measurement of $\mathrm{CO}_{2}$ was good qualitative indicator of bio mineralization. This similarity also existed for abiotic controls where the $\mathrm{CO}_{2}$ production stayed very low. It can be assumed that since OCPs are very persistent and complex compounds therefore free radicals did not play any role in their oxidation. Nevertheless, the inactivated extract, used as control, showed significantly less Endosulfan decrease than the activated SCME extract. This suggested that that both wash-off and volatilization had no impact on OCPs loss. This is in accordance with the studies conducted by Juárez et al. (2011). Since it is proved that Laccase and $\mathrm{MnP}$ have no role in bioremediation here, there could be another enzyme or enzymatic complex which is responsible for the degradation of Endosulfan. Although role of laccase in biodegradation of many pollutants has been widely studies (Karigar and Rao, 2011) but there is no direct evidence which connect the effect of presence or quantity of this enzyme in biodegradation of Endosulfan.

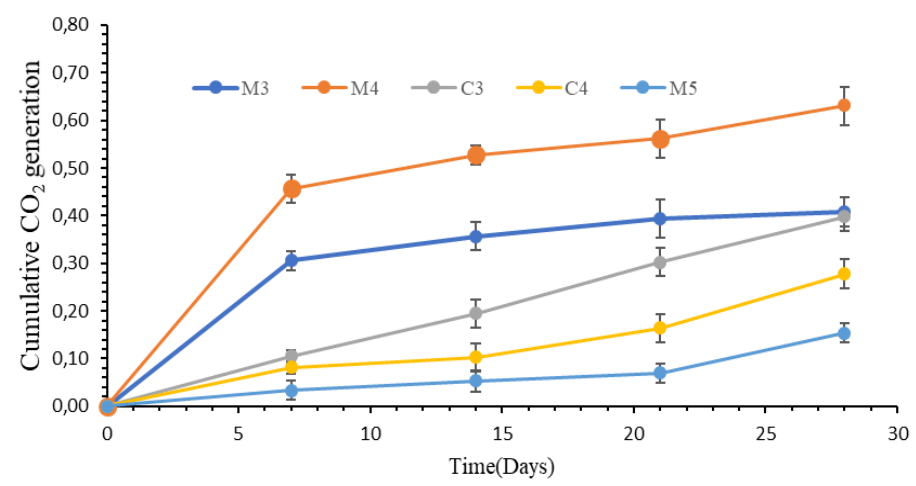

Figure 4. Evolution of $\mathrm{CO}_{2}$ during the incubation studies of the Endosulfan bioremediation by application SMCE treatments in soil, where $M_{1}$ is microcosm having fresh soil and SMCE and $M_{2}$ is microcosm that contain $\mathrm{H}_{2} \mathrm{O}_{2}$ along with while $C_{1}$ and $\mathrm{C}_{2}$ are the associated controls of microcosms 1 and 2. $M_{5}$ is the abiotic control microcosm

\section{Conclusion and recommendation}

In order to avoid the problem of adsorption, instead of its direct application spent mushroom compost extract was used to evaluate the role of enzyme complex in bioremediation of Endosulfan. Five different microcosms along with associated controls were used to demonstrate the role of SMCE. This study revealed that ligninolytic enzyme stimulation after addition of $\mathrm{H}_{2} \mathrm{O}_{2}$ does not affect the bioremediation efficacy of SMCE, rather it has certain other extracellular enzymes that could possibly be involved in process of decontamination. This was evident from almost equal reduction of this pesticide in the presence and absence of $\mathrm{H}_{2} \mathrm{O}_{2}$. In soil, this extract showed some effect of addition of $\mathrm{H}_{2} \mathrm{O}_{2}$. There was significantly more reduction of both isomers in the soil microcosm containing SMCE spiked with $\mathrm{H}_{2} \mathrm{O}_{2}$ than the other where $\mathrm{H}_{2} \mathrm{O}_{2}$ was not spiked. Associated controls showed if SCME was denatured after sterilization, there 
was less reduction in both isomers of Endosulfan. It also indicated the role of stimulation of indigenous soil microbes/enzymes in the presence of $\mathrm{H}_{2} \mathrm{O}_{2}$ and the role of SMCE as carbon source to enhance the microbial population of soil. All these results provide a basis for the development of new bioremediation strategy for decontamination of Endosulfan in soil. However, there is a strong need of understanding the complex nature of reactions involved in symbiotic interaction between SMCE and soil constituents which were responsible for more reduction of Endosulfan in soil.

Acknowledgements. We are thankful to Staff of Mushroom Research Laboratory, National Agriculture Research Centre, Islamabad, Pakistan for cooperation in mushroom culture, spawn and compost preparation. We are also very thankful to Soil Environment Lab for facilities of SMC and soil physicochemical properties. Many thanks to laboratory staff of Ecotoxicology Research Program especially, National Agriculture Research Centre, Islamabad, Pakistan.

\section{REFERENCES}

[1] Al-Hassan, R. M., Bashour, I. I, Kawar, N. S. (2004): Biodegradation of $\alpha$ and $\beta$ endosulfan in soil as influenced by application of different organic materials. - Journal of Environmental Science and Health, Part B 39(5-6): 757-764.

[2] Barcelo-Quintal, M. H., Cebada-Ricalde, M. C., Trejo-Irigoyen, A. R., Rendon-Osorio, R. B., Manzanilla-Cano, J. A. (2008): Kinetic studies of endosulfan photochemical degradations by ultraviolet light irradiation in aqueous medium. - Journal of Environmental Science and Health Part B 43(2): 120-126.

[3] Boes, E., Rosmalina, R. T., Ridwan, Y. S., Nugraha, W. C., Yusiasih, R. (2015): Development of validated method using QuEChERS technique for organochlorine pesticide residues in vegetable. - Procedia Chemistry 16: 229-236.

[4] Buah-Kwofie, A., Humphries, M. S. (2017): The distribution of organochlorine pesticides in sediments from iSimangaliso Wetland Park: Ecological risks and implications for conservation in a biodiversity hotspot. - Environmental Pollution 229: 715-723.

[5] Carvalho, F. P. (2017): Pesticides, environment, and food safety. - Food and Energy Security 6(2): 48-60.

[6] Chirnside, A. E. M., Ritter, W. F., Radosevich, M. (2011): Biodegradation of aged residues of atrazine and alachlor in a mix-load site soil by fungal enzymes. - Applied and Environmental Soil Science. http://dx.doi.org/10.1155/2011/658569.

[7] Cole, M. L. (1998): An Analysis of Composting as an Environmental Remediation Technology. - US-EPA Document. EPA, Washington, DC.

[8] Crawford, D. L., Ramachandra, M. (1993): Bacterial Extracellular Lignin Peroxidase. Google Patents.

[9] Dane, J. H., Topp, G. C., Campbell, G. S. (2002): Methods of Soil Analysis. Part 4: Physical Methods. - Soil Science Society of America, Madison, WI.

[10] Eichlerová, I., Homolka, L., Lisá, L., Nerud, F. (2006): The influence of extracellular $\mathrm{H}_{2} \mathrm{O}_{2}$ production on decolorization ability in fungi. - Journal of Basic Microbiology 46(6): 449-455.

[11] Ellouze, M., Sayadi, S. (2016): White-Rot Fungi and their Enzymes as a Biotechnological Tool for Xenobiotic Bioremediation. - In: Saleh, H. E.-D. M., Rahman, R. A. (eds.) Management of Hazardous Wastes. InTech, London.

[12] Fogarty, A. M., Tuovinen, O. H. (1991): Microbiological degradation of pesticides in yard waste composting. - Microbiological Reviews 55(2): 225-233.

[13] Guerin, T. F. (1999): The anaerobic degradation of endosulfan by indigenous microorganisms from low-oxygen soils and sediments. - Environmental Pollution 106(1): $13-21$. 
[14] Hageman, K. J., Christian, B., Martin, S. (2015): Long-range and regional atmospheric transport of POPs and implications for global cycling. - Comprehensive Analytical Chemistry 67: 363-387.

[15] Hatakka, A. (1994): Lignin-modifying enzymes from selected white-rot fungi: production and role from in lignin degradation. - FEMS Microbiology Reviews 13(2-3): 125-135.

[16] Hernandez-Rodriguez, D., Sánchez, J. E., Nieto, M. G., Márquez-Rocha, F. J. (2006): Degradation of endosulfan during substrate preparation and cultivation of Pleurotus pulmonarius. - World Journal of Microbiology and Biotechnology 22(7): 753-760.

[17] Hu, W., Huang, B., Zhao, Y., Sun, W., Gu, Z. (2014): Distribution, sources and potential risk of $\mathrm{HCH}$ and DDT in soils from a typical alluvial plain of the Yangtze River Delta region, China. - Environmental Geochemistry and Health 36(3): 345-358.

[18] Husaini, A. S. S. A. (2014): Bioremediation of crude oil by different fungal genera. Asian Journal of Plant Biology 2(1).

[19] Jayaraj, R., Megha, P., Sreedev, P. (2016): Organochlorine pesticides, their toxic effects on living organisms and their fate in the environment. - Interdisciplinary Toxicology 9(34): 90-100.

[20] Juárez, R. A. C., Dorry, L. L. G., Bello-Mendoza, R., Sánchez, J. E. (2011): Use of spent substrate after Pleurotus pulmonarius cultivation for the treatment of chlorothalonil containing wastewater. - Journal of Environmental Management 92(3): 948-952.

[21] Kamei, I., Takagi, K., Kondo, R. (2011): Degradation of endosulfan and endosulfan sulfate by white-rot fungus Trametes hirsuta. - Journal of Wood Science 57(4): 317.

[22] Karigar, C. S., Rao, S. S. (2011): Role of microbial enzymes in the bioremediation of pollutants: a review. - Enzyme Research 2011.

[23] Kataoka, R., Takagi, K. (2013): Biodegradability and biodegradation pathways of endosulfan and endosulfan sulfate. - Applied Microbiology and Biotechnology 97(8): 3285-3292.

[24] Ko, H. G., Park Sang Ho, Kim Seong Hwan, Park, H. G., Park, W. M. (2005): Detection and recovery of hydrolytic enzymes from spent compost of four mushroom species. Folia Microbiologica 50(2): 103-106.

[25] Kodjo-Wayo, L. K. (2006): Biodegradation and phytoremediation of polycyclic aromatic hydrocarbons using mushroom compost. - PhD Dissertation, University of Georgia.

[26] Kullman, S. W., Matsumura, F. (1996): Metabolic pathways utilized by Phanerochaete chrysosporium for degradation of the cyclodiene pesticide endosulfan. - Applied and Environmental Microbiology 62(2): 593-600.

[27] Lal, R., Pandey, G., Sharma, P., Kumari, K., Malhotra, S., Pandey. R., Raina, V., Kohler, H. E., Holliger, C., Jacksona, C. (2010): Biochemistry of microbial degradation of hexachlorocyclohexane and prospects for bioremediation. - Microbiology and Molecular Biology Reviews 74(1): 58-80.

[28] Lang, E., Nerud, F., Zadrazil, F. (1998): Production of ligninolytic enzymes by Pleurotus sp. and Dichomitus squalens in soil and lignocellulose substrate as influenced by soil microorganisms. - FEMS Microbiology Letters 167(2): 239-244.

[29] Li, X., Lin, X., Zhang, J., Wu, Y., Yin, R., Feng, Y., Wang, Y. (2010): Degradation of polycyclic aromatic hydrocarbons by crude extracts from spent mushroom substrate and its possible mechanisms. - Current Microbiology 60(5): 336-342.

[30] Lim, S., Lee, Y., Kang, H. (2013): Efficient recovery of lignocellulolytic enzymes of spent mushroom compost from oyster mushrooms, Pleurotus spp., and potential use in dye decolorization. - Mycobiology 41(4): 214-220.

[31] Manilal, V. B., Alexander, M. (1991): Factors affecting the microbial degradation of phenanthrene in soil. - Applied Microbiology and Biotechnology 35(3): 401-405.

[32] Marín-Benito, J. M., Sánchez-Martín, M. J., Rodríguez-Cruz, M. S. (2016): Impact of Spent Mushroom Substrates on the Fate of Pesticides in Soil, and Their Use for Preventing and/or Controlling Soil and Water Contamination: A Review. - Toxics 4(3): 17. 
[33] Márquez Araque, A. T., Martínez, G. D. M., Muñoz, S. S. G., Dios S E B, Corral O, L. (2007): Actividad fibrolítica de enzimas producidas por Trametes sp. EUM1, Pleurotus ostreatus IE8 y Aspergillus niger AD96. 4 en fermentación sólida. - Interciencia 32(11).

[34] Mukherjee, I. (2012): Influence of organic amendments on the degradation of endosulfan. - Bulletin of Environmental Contamination and Toxicology 89(2): 334-339.

[35] Nakajima, V. M, Soares, F. E., de Queiroz, J. H. (2018): Screening and decolorizing potential of enzymes from spent mushroom composts of six different mushrooms. Biocatalysis and Agricultural Biotechnology 13: 58-61.

[36] Ojuederie, O. B., Babalola, O. O. (2017): Microbial and Plant-Assisted Bioremediation of Heavy Metal Polluted Environments: A Review. - International Journal of Environmental Research and Public Health 14(12): 1504.

[37] Ozdal, M., Ozdal, O. G., Algur, O. F., Kurbanoglu, E. B. (2017): Biodegradation of $\alpha$ endosulfan via hydrolysis pathway by Stenotrophomonas maltophilia OG2. - Biotech 7(2): 113

[38] Özyer, A., Turan, N. G., Ardal1, Y. (2016): Degradation of Endosulfan in Different Soils by Indigenous and Adapted Microorganisms. - World Academy of Science, Engineering and Technology, International Journal of Environmental, Chemical, Ecological, Geological and Geophysical Engineering 10(4): 499-503.

[39] Papinutti, L., Forchiassin, F. (2010): Adsorption and decolorization of dyes using solid residues from Pleurotus ostreatus mushroom production. - Biotechnology and Bioprocess Engineering 15(6): 1102-1109.

[40] Paszczyński, A, Crawford R L, Huynh, V. (1988): Manganese peroxidase of Phanerochaete chrysosporium: purification. - Methods in Enzymology 161: 264-270.

[41] Paul, E. A., Harris, D., Collins, H. P., Schulthess, U., Robertson, G. P. (1999): Evolution of $\mathrm{CO}_{2}$ and soil carbon dynamics in biologically managed, row-crop agroecosystems. Applied Soil Ecology 11(1): 53-65.

[42] Purnomo, A. S., Mori, T., Kamei, I., Nishii, T., Kondo, R. (2010): Application of mushroom waste medium from Pleurotus ostreatus for bioremediation of DDTcontaminated soil. - International Biodeterioration \& Biodegradation 64(5): 397-402.

[43] Rice, C. P., Chernyak, S. M., Hapeman, C. J., Bilboulian, S. (1997): Air-water distribution of the endosulfan isomers. - Journal of Environmental Quality 26(4): 11011106.

[44] Ryan, J. (2017): Methods of Soil, Plant, and Water Analysis: A manual for the West Asia and North Africa region. - International Center for Agricultural Research in the Dry Areas (ICARDA), Beirut.

[45] SANCO (2017): Method Validation and Quality Control Procedures for Pesticide Residues Analysis in Food and Feed. - European Commission, Directorate General Health and Consumer Protection, SANTE/11813/2017 (Implemented by 01.01.2018).

[46] Schmidt, W. F., Bilboulian, S., Rice, C. P., Fettinger, J. C., McConnell, L. L., Hapeman, C. J. (2001): Thermodynamic, spectroscopic, and computational evidence for the irreversible conversion of $\beta$-to $\alpha$-endosulfan. - Journal of Agricultural and Food Chemistry 49(11): 5372-5376.

[47] Schoefs, O., Perrier, M., Samson, R. (2004): Estimation of contaminant depletion in unsaturated soils using a reduced-order biodegradation model and carbon dioxide measurement. - Applied Microbiology and Biotechnology 64(1): 53-61.

[48] Siddique, T, Okeke, B. C., Arshad, M., Frankenberger, W. T. (2003): Enrichment and isolation of endosulfan-degrading microorganisms. - Journal of Environmental Quality 32(1): 47-54.

[49] Singh, T., Singh, D. K. (2017): Phytoremediation of organochlorine pesticides. International Journal of Phytoremediation 19(9): 834-843.

[50] Sparks, D. L., Helmke, P. A., Page, A. L. (1996): Methods of Soil Analysis. Part 3: Chemical Methods. - SSSA, Madison, WI. 
[51] Tandon, H. L. S. (2005): Methods of analysis of soils, plants, waters, fertilizers \& organic manures. - Fertilizer Development and Consultation Organization.

[52] Tien, M., Kirk, T. K. (1988): Lignin peroxidase of Phanerochaete chrysosporium. - In Methods in enzymology, 238-249. Elsevier.

[53] Tsai, W. (2010): Current status and regulatory aspects of pesticides considered to be persistent organic pollutants (POPs) in Taiwan. - International journal of environmental research and public health 7(10): 3615-3627.

[54] Ulčnik, A., Cigić, I. K., Pohleven, F. (2013): Degradation of lindane and endosulfan by fungi, fungal and bacterial laccases. - World Journal of Microbiology and Biotechnology 29(12): 2239-2247.

[55] Uqab, B., Mudasir, S., Nazir, R. (2016): Review on Bioremediation of Pesticides. Journal of Bioremediation and Biodegradation 7(343): 2.

[56] Valentin, C. L. (2010): Two ex situ fungal technologies to treat contaminated soil. Dissertation, University of Helsinki, Finland.

[57] Vyas, B. R., Molitoris, H. (1995): Involvement of an extracellular $\mathrm{H}_{2} \mathrm{O}_{2}$-dependent ligninolytic activity of the white rot fungus Pleurotus ostreatus in the decolorization of Remazol brilliant blue R. - Applied and environmental microbiology 61(11): 3919-3927.

[58] Wang, W., Wang, Y., Zhang, R., Wang, S., Wei, C., Chaemfa, C., Li, J., Zhang, G., Yu, K. (2016): Seasonal characteristics and current sources of OCPs and PCBs and enantiomeric signatures of chiral OCPs in the atmosphere of Vietnam. - Science of the Total Environment 542: 777-786.

[59] Yadav, I. C., Devi, N. L., Li, J., Zhang, G., Breivik, K. (2017): Possible emissions of POPs in plain and hilly areas of Nepal: implications for source apportionment and health risk assessment. - Environmental pollution 220: 1289-1300.

[60] Yang, C., Wang, C., Chen, C. (2014): Di-n-butyl phthalate removal by strain Deinococcus sp. R5 in batch reactors. - International Biodeterioration \& Biodegradation 95: 55-60.

[61] Zhang, J., Zhang, J., Liu, R., Gan, J., Liu, J., Liu, W. (2015): Endocrine-disrupting effects of pesticides through interference with human glucocorticoid receptor. - Environmental science \& technology 50(1): 435-443.

[62] Zhang, W., Wang, X., Wang, S. (2013): Addition of external organic carbon and native soil organic carbon decomposition: a meta-analysis. - Plos One 8(2): e54779. 